\title{
The Classroom as Panopticon; Protecting Your Rights in the Technology- Enhanced Workplace
}

\author{
Marita Moll ${ }^{1}$
}

The history of the Industrial Revolution is the history of increasing product and profit through the efficiencies afforded by increasing control over the process. As industrialization progressed through its various phases, one outcome was always predictable. The movement of workers would be more carefully choreographed, production would be more closely planned and monitored, and the gathering and distribution of information would be in the hands of fewer and fewer people. Despite the rhetoric of the information age and the knowledge revolution, the future is beginning to look a great deal like the past on steroids. Efficiency-mania has tightened its grip on the workplace and threatens to leave no sector untouched - not even education. ${ }^{2}$ Recent reforms, especially the demands of accountability through intensive measurement, are designed to make education increasingly "outcomes-based." It is getting harder to tell that education is, as Neil Postman so eloquently puts it, about "creating a public"3 not about creating a product.

It is possible that one thing slowing down the rationalization or taylorization ${ }^{4}$ of the work of teachers is the general confusion and lack of planning around the agenda to computerize the classroom - no support, little training, unreliable software and non-existent curriculum. But this may be only a temporary reprieve. Combining electronically- delivered standardized curricula with built-in feedback mechanisms, the soon- to-be prolific PC-based cameras and video-conferencing systems, and Web and e-mail monitoring capabilities, every move, every word, every action in the classroom can be subject to instant replay. This future is already at our doorstep. A recent article in the Wall Street Journal promoted the benefits of the child-care camera. Apparently some nursery schools now allow parents to have video-cameras connected to the Internet installed at the schools. That way the parents can keep an eye on their child and everyone else in the vicinity from their workstations all day long. ${ }^{5}$ The intention is to assuage guilt-ridden parents but the impact may well be a generation of kids so accustomed to surveillance that they will feel insecure without a camera pointed in their direction. The shadow of Big Brother looms large.

Those who believe new technologies will lead to more choices and greater freedom for everyone haven't yet shown how they expect to turn these processes off once they find their way into the system. With all the evidence about the bias of control in the new technologies, the classroom, too, can become a panopticon. 


\section{The blinking sensor}

There is a new gadget on the market designed to control the bathroom habits of those who work in the food services sector:

Hygiene Guard - a badge that would be worn by employees. It triggers an infrared sensor when the worker enters the washroom. A sensor at the soap dispenser activates if the employee stays at the sink for at least 15 seconds. The electronic record notes when he uses the washroom and whether he stops at the sink. The badge blinks if he skips the soap! ${ }^{6}$

In the highly efficient technology enhanced workplace, workers learn to watch themselves. David Lyon calls it "anticipatory conformity." Workers forced to wear this badge are unlikely to test the system by not washing their hands. The blinking sensor would be a modern equivalent of an earlier form of public punishment that called for locking offenders in "stocks" on the public square.

In other fields of work, including education, the new technologically-based forms of control may be more subtle, but no less effective. In Pennsylvania, everything from the career goals of high school graduates to the absenteeism rate of teachers can be found on the Internet. School profiles - statistics ranging from test scores to school district finances — are available for all 501 districts, making Pennsylvania one of the first states in the nation to offer the public such a comprehensive look at their classrooms via computer. Also planned is a database that would allow the public to compare schools. ${ }^{8}$

Suppose your neighbourhood school doesn't make the top 10 in the comparative ratings game, ratings which ignore most of the variables that go into the mix of teacher/student populations in a community called "school." When that sensor blinks — someone is guilty of something. Maybe it is the teachers — whose absenteeism rate, blinking like a sensor for all the world to see, is a little above the average.

Constant monitoring in any workplace is demeaning and demoralizing. With an increasing number of workplaces, from the classroom to the supermarket, going on-line, employees need some protection from the prying eyes of Big Brother. The erosion of privacy as it affects our lives as citizens and consumers has its public advocates who lobby to keep the issue on the public agenda. But in a world where unions are daily losing ground to the globalization juggernaut, those looking out for the privacy concerns in the workplace are finding it hard to get anyone's attention. All privacy advocates should be adding the following documents to their basic toolkit of resources.

\section{If you are reading this Webpage at work}

The data collection capabilities of Web browsers and Websites are becoming more sophisticated every day. How often are employees instructed on how to protect themselves from surveillance while Web browsing? Labour activist Eric Lee has posted a resource on "Labour Start" called "If you are reading this web page at work, you might lose your job" (http://www.labourstart.org/labour04.html). In very user friendly language he describes how to clear your cache which keeps a copy of Web pages you recently visited, how to clear the history list which stores the addresses of those pages, and the location bar list - another place where your Web visits are stored. It tells you how to get rid of cookies - those data trails you leave behind for Websites to pick up — how to really delete files and how to use Web-based services for e-mail to avoid storing e-mail on the company computer. This very user-friendly guide should be widely promoted as basic information necessary for anyone using a computer at work. 


\section{Collective action}

The International Federation of Commercial, Clerical, Professional and Technical Employees (FIET), representing 11,000,000 workers in 120 countries has drawn its line in the sand on workplace surveillance.

- There should be no electronic monitoring by employers of e-mail sent or websites visited by employees.

In addition, FIET, in this campaign called "On-line Rights for On-line Workers" calls for:

- The right of free access by employees and by trade unions and works councils to corporate email systems, so that employee members can receive information and communicate with their representatives.

- The right of free access to the Internet (and to corporate intranet networks) by employees, to enable them to access trade union web sites and other information relevant to their rights at work.

The "On-line rights for on-line workers" campaign documentation (http://www.labourstart.org/ onlinerights/bibby.htm) provides model collective agreement language to ensure that employee rights to access and privacy while using on-line communications media are protected. It is a model that protects employers while respecting the rights of employees, a model any company or institution should be able to live with.

\section{Fixing the safety net}

It is illegal in many countries to willfully intercept private communications, to open private letters, or to tape phone calls. In Canada, the penalty is five years in jail for anyone, employers included, found guilty of such activities. Employers can get around this by advising employees clearly that they have no right to privacy in the workplace, but few employers feel the need or desire to take such draconian measures.

Why have we allowed e-mail to slip through this social and legal safety net? Most electronic networks and e-mail software packages depend on user id and passwords to identify users. So your email is enclosed in an envelope of sorts. Considered this way, it is not just a postcard, but a letter, enclosed in an envelope. It may be no harder to open than a paper envelope, but, unless you are suspected of breaking the law, no one should have a right to open that envelope without your permission. We must begin now to distance ourselves from the "it's only a postcard" rhetoric which has become part of the accepted dogma of on-line communications. Under these conditions one has to wonder, when telephone and Internet communications are converged, as they already are in some places, which practices will prevail?

It is not unreasonable or impossible to regain some of the ground we have lost with respect to communications privacy in the workplace. We must begin to use the mechanisms of social and legal constraints and apply them as they are applied to other communications media. We must not see this as purely a technological problem. Some technological solutions may be helpful. But, in the final analysis, this is a social problem which demands a social solution.

\section{References}

${ }^{1}$ Marita Moll is the head of research and technology at the Canadian Teachers' Federation (CTF), and a volunteer research associate for the Canadian Centre for Policy Alternatives (CCPA) 
${ }^{2}$ Moll, Marita (2000). "If It's Only A Tool, Whose Tool Is It? Teachers, Technologies and the New World of Work" in Moll, Marita ((ed) But It's Only A Tool; The Politics of Technology and Education Reform. Ottawa: Canadian Centre for Policy Alternatives.

${ }^{3}$ Postman, Neil. (1995). The End of Education: Redefining the Value of School. New York, NY: Alfred A. Knopf. p.18.

${ }^{4}$ Taylorism is "the unifying and underlying philosophy of all modern management in so far as its essence is an emphasis on the necessity for management to monitor, analyse and thoroughly plan the activities that are the concern of the corporation." (Robins, Kevin and Frank Webster (1989). The Technical Fix: Education, Computers and Industry. New York, NY: St. Martin's Press. p. 38.) ${ }^{5}$ Shellenbarger, Sue (1998). “Work \& Family." Wall Street Journal, August 19

${ }^{6}$ (1997, May 27) "Big brother is washing." Ottawa Citizen

${ }^{7}$ Lyon, David (1994). The Electronic Eye; The Rise of Surveillance Society. Minneapolis: University of Minnesota Press.

${ }^{8}$ Russell, Heidi.(1997, June 24) Associated Press. Philadelphia Inquirer, Tuesday 